\title{
Effect of Irrigation Scheduling at Different Management Allowable Deficit Using Pan Evaporation on Wheat Yield and Water efficiencies at North Delta
}

\author{
Elsayed Moursi', Ramy M. Khalifa ${ }^{2 *}$, Ahmed M. Meleha ${ }^{3}$, and Mahmoud A. Aiad ${ }^{1}$ \\ ${ }^{1}$ Soils Improvement Dept., Soils, Water and Environment Research Institute, Sakha Agric. \\ Res. Station, \\ ${ }^{2}$ Soils Department -Faculty of Agriculture Damietta University-Damietta, \\ ${ }^{3}$ Water Management Research Institute, National Water Research Center, Egypt
}

$\mathbf{T}$ wo field experiments were carried out at Sakha farm, Kafr El-Sheikh Governorate during 2016/2017 and 2017/2018 to investigate the effect of irrigation scheduling at different allowable soil moisture depletion (ASMD) levels by using Pan evaporation method (PEM) on wheat yield and water efficiencies at North Delta. Four irrigation treatments; 40, 50, 60, and $70 \%$ ASMD denoted as $I_{1} I_{2}, I_{3}$ and $I_{4}$, respectively. The design of the experiment was randomized complete block with three replicates. The obtained results showed that the highest amount of seasonal water applied was recorded under PEM at 60\%ASMD. Meanwhile, the lowest value was recorded with $\mathrm{I}_{4}$ treatment in both seasons. Both of actual water consumptive use and water stored have the same order; $\mathrm{I}_{3}>\mathrm{I}_{2}>\mathrm{I}_{1}>\mathrm{I}_{4}$. The highest water application efficiency values were achieved with $\mathrm{I}_{4}$ treatment. Irrigation treatment $\left(\mathrm{I}_{1}\right)$ surpassed the other irrigation treatments in increasing the water productivity, productivity of irrigation water, wheat yields and its components as well as grain yield, total seasonal return, net seasonal revenue and benefitcost ratio.Irrigation treatment $I_{1}$ has superiority in increasing the grain yield by $(4.36,9.86$ and $13.18 \%) \&(1.33,7.17$ and $10.55 \%)$ for $\mathrm{I}_{2}, \mathrm{I}_{3}$ and $\mathrm{I}_{4}$, in the $1^{\text {st }}$ and $2^{\text {nd }}$ seasons respectively.Under the conditions of the current study, irrigation treatment $\mathrm{I}_{1}$ (irrigation scheduling by PEM at $40 \%$ ASMD) is the proper treatment to obtain the higher production of wheat crop and higher profitability.

Keywords: Irrigation Scheduling, Pan evaporation, Economic return, Grain yield, Water efficiencies, Water consumptive use, Wheat plant.

\section{Introduction}

Under the water shortage facing Egypt due to the high annual rate of increasing national population along with the fixed allocation from Nile River. The situation results in decreasing the annual share per capita from water to less than the water poverty edge of $1000 \mathrm{~m}^{3}$. Moreover, this share expected to be less thanthe level of $500 \mathrm{~m}^{3}$ in the few coming decades.In Egypt agriculture relies greatly on irrigation water from Nile River, where the agriculture sector consumes more than $84 \%$ of the available water resources (ELBeltagy and Abo Hadeed., 2008). However, water productivity is very low. Water users normally over irrigate their fields because the lack of proper knowledge about irrigation scheduling; and with the interesting that more water will produce more yield. However, more applications of water may result in low water productivity and low net income (Ashraf et al., 2001). Irrigation scheduling is very critical for obtaining optimal crop yields. For optimum irrigation scheduling, sound knowledge of the soil water status, crop water requirements, crop water stress status, and potential yield reduction under water stressed conditions is prerequisite to maximize profits and optimize the use of water and energy (Wen et al. 2017 and Wei et al. 2018). There are different methods of irrigation scheduling viz., critical crop growth stage approach, soil moisture depletion approach (whether in terms of soil water content or soil water potential), atmospheric evaporativity approach, irrigation water at different cumulative pan evaporation approach, etc. can be adopted for optimizing the timing of irrigation.Using pan

"Corresponding author: dr_ramykhalifa@yahoo.com

DOI: $10.21608 /$ jsas.2018.6488.1115

(C)2019 National Information and Documentation Centre (NIDOC) 
evaporation for irrigation scheduling has been calculated by many workers in Egypt (Khalil, 1996; Ashraf et al.2002; Khalil et al, 2006) and it was proven to save up to $20 \%$ of the applied irrigation water.

Wheat (TriticumaestivumL.) is one of the important leading cereal crops regarding area and production in the world. Also wheat is important and most strategic crop in Egypt (Karrou et al, 2012). However, at the national level, there is a wide gap among wheat consumption and production varying from 40 to $50 \%$. Due to the fast growth of population, maximizing wheat production should be achieved through cultivation of the high yielding wheat cultivars and appropriate agronomic practices such as irrigation, sowing pattern and its date, fertilizer and weed control. Sharshar (2010), AL Tahar et al. (2011), EL-Hag (2012), Zafarnaderi and Mohammadi (2013), Omar et al. (2014), Belal Hossain et al. (2015) and Zhang et al. (2017) showed that plants height, number ofspikes $\mathrm{m}^{-2}$, grain and straw yields, harvest index, number of grains/spike and thousand grain weight were affected by different irrigation number.

Regarding to the effect of soil moisture depletion levels on wheat productivity, Beshara (2012) and EL-Agrodi et al. (2016) found that the highest mean value of wheat yields and biological yield were produced with $40 \%$ depletion of available water and application the first dose of nitrogen fertilizer at sowing and the remaining were applied before the successive irrigations in both seasons. Also, the growth indicators (plant height, spike length, average number of tillers per plant and weight of 1000 kernels) increased as the available soil moisture content and the number of $\mathrm{N}$-dose increased. Data showed that the highest values of water application efficiency $(\mathrm{Ea})$, field water use and crop water use efficiencies were obtained under $40 \%$ of available water in the two seasons.

Regarding to the shortage andlimited of water resources in Egypt, and using it in a lot of fields particularly in Agriculture, it demands to save much water by using different techniques in irrigation without decreasing the productivity of crops. So, the aim of this studyis to evaluate the effect of irrigation scheduling at different allowable soil moisture depletion levels by using pan evaporation method on wheat yield and some water relations at North Delta.

\section{Materials and Methods}

\section{Experimental design}

This study was conducted at Sakha experimental Farm, Kafr El-Sheikh Governorate. Site is located at $31^{\circ} 07^{-} \mathrm{N}$ latitude and $30^{\circ} 57^{-}$ E longitude with an elevation of about 6 meters above sea level during winter seasons of 2016/2017 and 2017/2018. This location represented the conditions of the North Delta region.

\section{The approach of pan evaporation method}

To define the time of irrigation, measure water use for a short period of time, keeping track of the value or depth at the start of the season or when the pan is refilled following heavy rain or irrigation. A check book is used to schedule irrigations. The value for daily water use or for a few days is subtracted from the stored soil water is exhausted, it is time to irrigate. The design of the experiment was randomized complete block (RCB) with 3 blocks formed i.e. (A, B and C), Table (1) and 4 treatments:

$\mathrm{I}_{1}$ : irrigation depth applied $59.7 \mathrm{~mm} \mathrm{(40 \%}$ $\times 149.2 \mathrm{~mm}$ ) according to allowable soil moisture depletion at $40 \%$ of available water had evaporated from pan evaporation.

$\mathrm{I}_{2}$ : irrigation depth applied $74.6 \mathrm{~mm} \mathrm{(50 \%}$ $\times 149.2 \mathrm{~mm}$ ) according to allowable soil moisture depletion at $50 \%$ of available water had evaporated from pan evaporation.

$\mathrm{I}_{3}$ : irrigation depth applied $89.5 \mathrm{~mm}(60 \%$ $\times 149.2 \mathrm{~mm}$ ) according to allowable soil moisture depletion at $60 \%$ of available water had evaporated from pan evaporation.

$\mathrm{I}_{4}$ : irrigation depth applied $104.4 \mathrm{~mm}(70 \%$ $\times 149.2 \mathrm{~mm}$ ) according to allowable soil moisture depletion at $70 \%$ of available water had evaporated from pan evaporation.

Taking intoconsideration pan coefficient (0.8), crop coefficient of wheat for different growth stages was taken from FAO irrigation and drainage technical paper No.56.

The inflow rate was measured with a rectangular sharp crested weir. The flow rate was measured using the equation as described by (Masoud, 1969).

\section{$\mathrm{Q}=\mathrm{C} \mathrm{L} \mathrm{H} \mathrm{H}^{3 / 2}$}

where: $\mathrm{Q}=$ discharge $\left(\mathrm{m}^{3} / \mathrm{sec}.\right), \mathrm{L}=$ length of the crest in meters, $\mathrm{H}=$ head in meters, 
$\mathrm{C}=$ Empirical coefficient that must be determined from discharge measurement.

\section{Experimentlayout:}

Based on design, the total 12 plots with an average field size of $7.5 \mathrm{~m}$ length $\times 7 \mathrm{~m}$ width. An irrigation channel ditch of one-meter width was already existed on the sides of the field to ensure easy access of water to each plot. Wheat variety Sakha 93 planted on $18^{\text {th }}$ and $20^{\text {th }}$ November and harvesting operation was performed on $19^{\text {th }}$ and $23^{\text {rd }}$ April in the first and second seasons, respectively. All agricultural practices were implemented as recommended by Agriculture Research center (ARC) for the studied crop and area, except the studied treatments (irrigation treatments).
- Some soil characters:The textural class of soil was determined according to the pipette method as described by Dewis and Fartias (1970). Soil samples were collected from four depths $(0-15,15-30,30-45$ and $45-60 \mathrm{~cm})$. Field capacity (F.C) and permanent wilting point (PWP) were determined using pressure membrane at 0.33 and 15 atm(Klute, 1986). Soil bulk density was determined according to Klute (1986), as shown in Table 2.

- Some soil chemical properties(total soluble salts, soil reaction $\mathrm{pH}$, soluble cations and anions were determined in the studied site according to methods described by Jackson (1973), as shown in Table 3.

TABLE 1. The experimental design

\begin{tabular}{|c|c|c|c|}
\hline S.NO. & variable & level & Remarks \\
\hline 1 & Irrigation depths treatment & 4 & $\begin{array}{c}\text { Irrigation was applied according to different allowable } \\
\text { soil moisture depletion of available water }(40,50,60 \text { and } \\
70 \%)\end{array}$ \\
\hline 2 & Replications & 3 & Three blocks were formed i.e. A,B and c \\
\hline 3 & Total number of experimental units & & $3 \times 4=12$ plots \\
\hline
\end{tabular}

TABLE 2. Mean values for some physical properties of the experimental site

\begin{tabular}{|c|c|c|c|c|c|c|c|c|}
\hline \multirow{2}{*}{$\begin{array}{c}\text { Soil } \\
\text { depth }\end{array}$} & \multicolumn{3}{|c|}{ Particle size distribution } & \multirow{2}{*}{$\begin{array}{c}\text { Textural } \\
\text { class }\end{array}$} & \multirow{2}{*}{$\begin{array}{l}\text { F.C. } \\
(\%)\end{array}$} & \multirow{2}{*}{$\begin{array}{l}\text { PWP } \\
(\%)\end{array}$} & \multirow{2}{*}{$\begin{array}{l}\text { AW } \\
(\%)\end{array}$} & \multirow{2}{*}{$\begin{array}{c}\text { Bulk density } \\
\left(\mathrm{Mg} \mathrm{m}^{-3}\right)\end{array}$} \\
\hline & Sand $(\%)$ & Silt (\%) & Clay (\%) & & & & & \\
\hline $0-15$ & 17.14 & 23.9 & 58.96 & clayey & 44.5 & 22.52 & 21.98 & 1.12 \\
\hline $15-30$ & 18.86 & \multicolumn{2}{|c|}{$\begin{array}{c}\text { silt } 24.4 \\
\text { clay } 56.74\end{array}$} & clayey & 41.1 & 20.65 & 20.45 & 1.21 \\
\hline $30-45$ & 18.99 & 24.12 & 56.89 & clayey & 38.9 & 20.1 & 18.8 & 1.31 \\
\hline $45-60$ & 18.16 & 24.89 & 56.95 & clayey & 38.15 & 19.8 & 18.35 & 1.34 \\
\hline Mean & 18.29 & 24.33 & 57.38 & clayey & 40.66 & 20.77 & 19.89 & 1.25 \\
\hline
\end{tabular}

F.C. $=$ Field capacity, $\mathrm{PWP}=$ permanent wilting point, $\mathrm{AW}=$ Available Water. 
TABLE 3. Mean values for some chemical properties of the experimental site

\begin{tabular}{|c|c|c|c|c|c|c|c|c|c|c|}
\hline \multirow{2}{*}{$\begin{array}{c}\text { Soil } \\
\text { depth } \\
(\mathrm{cm})\end{array}$} & \multirow{2}{*}{ 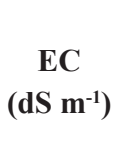 } & \multirow{2}{*}{$\begin{array}{c}\text { pH }(1: 2.5) \\
\text { soil water } \\
\text { suspension }\end{array}$} & \multicolumn{4}{|c|}{ Soluble cations $\left(\mathrm{meq} \mathrm{L}^{-1}\right)$} & \multicolumn{4}{|c|}{ Soluble anions (meq $\left.L^{-1}\right)$} \\
\hline & & & $\mathbf{N a}^{+}$ & $\mathbf{K}^{+}$ & $\mathrm{Ca}^{++}$ & $\mathbf{M g}^{++}$ & $\mathrm{CO}_{3}=$ & $\mathrm{HCO}_{3}^{-}$ & $\mathbf{C L}^{-}$ & $\mathrm{SO}_{4}=$ \\
\hline $0-15$ & 2.22 & 8.77 & 17.6 & 0.3 & 5.0 & 1.5 & - & 3.0 & 7.1 & 14.3 \\
\hline $15-30$ & 2.63 & 8.69 & 16.0 & 0.6 & 7.6 & 5.3 & - & 5.0 & 8.2 & 16.3 \\
\hline $30-45$ & 2.96 & 8.64 & 24.4 & 0.2 & 8.4 & 4.3 & - & 3.0 & 13.3 & 21.0 \\
\hline $45-60$ & 3.7 & 8.26 & 33.8 & 0.2 & 3.0 & 2.1 & - & 4.0 & 11.2 & 23.9 \\
\hline Mean & 2.88 & - & 22.95 & 0.33 & 6.0 & 3.3 & - & 3.8 & 9.95 & 18.9 \\
\hline
\end{tabular}

TABLE 4. Meteorological data for Kafr El-Sheikh area during the two growing seasons

\begin{tabular}{|c|c|c|c|c|c|c|c|c|c|}
\hline \multirow{2}{*}{ Month } & \multicolumn{3}{|c|}{$\mathbf{T}\left(\mathbf{c}^{0}\right)$} & \multicolumn{3}{|c|}{ RH\% } & \multirow{2}{*}{$\begin{array}{c}\text { WS km/ } \\
\text { day }\end{array}$} & \multirow{2}{*}{$\begin{array}{l}\text { Pan evapo. } \\
\text { mm/month }\end{array}$} & \multirow{2}{*}{$\begin{array}{c}\text { Rain } \\
\text { (mm /month) }\end{array}$} \\
\hline & Max. & Min. & Mean & Max. & Min. & mean & & & \\
\hline \multicolumn{10}{|c|}{$1^{\text {st }}$ season } \\
\hline Nov.2016 & 24.9 & 17.9 & 21.4 & 77.9 & 56.8 & 67.35 & 56.0 & 198.1 & - \\
\hline Dec.2016 & 19.3 & 10.8 & 15.05 & 85.4 & 65.1 & 75.25 & 64.7 & 156.4 & 14.54 \\
\hline Jan.2017 & 18.2 & 5.7 & 11.95 & 87.3 & 62.9 & 75.10 & 51.9 & 136 & 9.6 \\
\hline Feb.2017 & 19.7 & 10.2 & 14.95 & 85.8 & 60.1 & 72.95 & 59.3 & 214.4 & 9.6 \\
\hline March2017 & 21.7 & 17.9 & 19.8 & 84.9 & 60.4 & 72.65 & 83.8 & 295.4 & - \\
\hline April2017 & 26.5 & 21.6 & 24.05 & 79.4 & 50.8 & 65.10 & 89.3 & 463.8 & 10.6 \\
\hline \multicolumn{10}{|c|}{$2^{\text {nd }}$ season } \\
\hline Nov.2017 & 23.7 & 19.9 & 21.8 & 84.7 & 58.6 & 71.65 & 53.16 & 206.2 & 9.3 \\
\hline Dec. 2017 & 21.5 & 18.4 & 19.95 & 88.2 & 64.8 & 76.5 & 42.9 & 147.8 & 5.9 \\
\hline Jan.2018 & 19.3 & 13.9 & 16.6 & 88.4 & 63.7 & 76.05 & 49.3 & 185.1 & 36.4 \\
\hline Feb.2018 & 21.6 & 14.9 & 18.1 & 87.6 & 63.4 & 75.5 & 34.7 & 277.5 & 16.6 \\
\hline March2018 & 25.4 & 16.6 & 21.0 & 82.3 & 48.3 & 65.3 & 46.4 & 421.9 & - \\
\hline April2018 & 27.8 & 20.0 & 23.9 & 80.9 & 43.9 & 62.4 & 74.0 & 531.6 & - \\
\hline
\end{tabular}

WS km/day at $2 \mathrm{~m}$ height

Source: Meteorological station at Sakha Agriculture Research station.

\section{Water measurements}

Water consumptive use (Eta, m3fed-1)

Gravimetric method was used to determine thesoil moisture to compute the actual water consumptive use based upon soil moisture depletion (SMD). The actual water consumptive use (Eta) was calculated by Hansen et al. (1979).

\section{$\mathrm{E}=\mathrm{S} \mathrm{SMD}=\sum_{\mathrm{i}=1}^{i=1} \theta 2-\theta 1 / 100 \times$ Dbi $\times$ Di $\times A$}

where: Eta $=$ water consumptive use $\left(\mathrm{m}^{3}\right), \theta 2=$ soil moisture $\%$ after irrigation in the $i^{\text {th }}$ layer, $\theta 1=$ soil moisture $\%$ before the next irrigation in the $i^{\text {th }}$ layer, Dbi $=$ Bulk density $\left(\mathrm{Mgm}^{-3}\right)$ of the $i^{\text {th }}$ layer, $\mathrm{Di}=$ depth of the $\mathrm{i}^{\text {th }}$ layer $(\mathrm{m}), \mathrm{A}=$ irrigated area $\left(\mathrm{m}^{2}\right), \mathrm{I}=$ number of soil layers and $n=$ number of irrigations.

Water stored in the effective root zone (Ws) Calculated using equation of:

\section{$W=\sum_{i=1}^{i=\pi} \theta 2-61 / 100 \times$ Dbi $\times$ Di $\times A$}


where: $\theta 2=$ soil moisture $\%$ after irrigation in the $\mathrm{i}^{\text {th }}$ layer, $\theta 1=$ soil moisture $\%$ before irrigation in the $\mathrm{i}^{\text {th }}$ layer, (i.e directly, before and after the same irrigation, $\mathrm{Dbi}=$ Bulk density in $\left(\mathrm{Mgm}^{-3}\right), \mathrm{Di}=$ depth of the $\mathrm{i}^{\text {th }}$ layer, $\mathrm{A}=$ irrigated area $\left(\mathrm{m}^{2}\right)$.

Water application efficiency(Ea)

It is the ratio between the amount of stored water $\left(\mathrm{m}^{3} \mathrm{fed}^{-1}\right)$ and water applied $\left(\mathrm{m}^{3} \mathrm{fed}^{-1}\right)$ as described by Downy (1970).

$$
\mathrm{Ea}=(\mathrm{ws} / \mathrm{wa}) \times 100
$$

where:ws and wa are the volumetric water stored and the volumetric water applied respectively.

Water productivity: (WP,kg $\mathrm{m}$-3)

It was calculated according to Ali et al. (2007) as follows:

$$
\mathrm{Wp}=\mathrm{Gy} / \mathrm{ET}
$$

where: $\mathrm{Wp}=$ water productivity $\left(\mathrm{kgm}^{-3}\right), \mathrm{Gy}=$ grain yield $\left(\mathrm{kgfed}^{-1}\right) . \mathrm{ET}=$ total water consumption.

Productivity of irrigation water (PIW, kgm-3) It was calculated according to Ali et al. (2007)

$$
\mathrm{PIW}=\mathrm{Gy} / \mathrm{wa}
$$

where: Wa $=$ irrigation water applied. $\left(\mathrm{m}^{3} \mathrm{fed}^{-1}\right)$, $\mathrm{Gy}=$ grain yield $\left(\mathrm{kgfed}^{-1}\right)$

\section{Yield and some yield attributes}

- Plant height (cm): was measured from the soil surface to the tip of the spikes excluding awns.

-Spike length (cm): Average spike length for ten randomly chosen spikes.

-1000 grain weight (g): Random samples of 1000 grain were taken from each plot, hand counted and weighed $(\mathrm{g})$.

-Biological yield(tonfed-1): it was recorded for the harvested area and then it was converted to tonfed-1.
- Grain yield (kgfed-1): was recorded for the harvested area after threshing at14.5\% moisture content.

- Straw yield (tonfed-1):was estimated in (kg m-2) by subtracting grain yield $(\mathrm{kg} \mathrm{m}-2)$ from total yield (kg m-2), then it was converted to ton fed-1.

- Harvest index (HI):grain yield ratio with the total above ground dry matter of each plot.

All data were statistically analyzed according Gomez and Gomez (1984).

\section{Economic evaluation}

Cash inflows and outflows for various treatments (at prices of the Egyptian local market) were calculated, and some economic indicators were estimated such as:

- Net return: it can be calculated by deducting the total cost from the total return, (L.E fed ${ }^{-1}$.)

- Benefit cost ratio (BCR): it can be determined by dividing the total seasonal return on total seasonal cost, (Atiea, 1986).

- Return per unit of water:This can be taken as index to the relationship between Net return $\left(\right.$ L.E fed $\left.{ }^{-1}\right)$ and water applied $\left(\mathrm{m}^{3} \mathrm{fed}^{-1}\right)$.

\section{Results And Discussion}

\section{Effect of treatments on}

Irrigation interval and number of irrigation applied

During the growing season of wheat, four irrigations were applied for the $\mathrm{I}_{1}, \mathrm{I}_{2}$ and $\mathrm{I}_{3}$ treatments, while $\mathrm{I}_{4}$ received three irrigations because of frequent, amount of rainfall and variation in depth of water applied to different irrigation treatments. The irrigation interval between irrigation was also not uniform due to precipitation and different depth of water applied as shown in Table 5.

TABLE 5. Date of irrigation and irrigation interval for different treatments

\begin{tabular}{cccccccc}
\hline $\begin{array}{c}\text { Irrigation } \\
\text { treatments }\end{array}$ & $\begin{array}{c}\text { Planting } \\
\text { irrigation }\end{array}$ & $\begin{array}{c}\text { First } \\
\text { irrigation }\end{array}$ & $\begin{array}{c}\text { Irrigation } \\
\text { intervals } \\
\text { days }\end{array}$ & $\begin{array}{c}\text { Second } \\
\text { irrigation }\end{array}$ & $\begin{array}{c}\text { Irrigation } \\
\text { intervals } \\
\text { days }\end{array}$ & $\begin{array}{c}\text { Third } \\
\text { irrigation }\end{array}$ & $\begin{array}{c}\text { Irrigation } \\
\text { intervals } \\
\text { days }\end{array}$ \\
\hline $\mathrm{I}_{1}$ & Nov.18 & Dec.9 & 21 & Jan.31 & 53 & March,2 & 30 \\
$\mathrm{I}_{2}$ & Nov.18 & Dec.9 & 21 & Feb.6 & 59 & March, 14 & 36 \\
$\mathrm{I}_{3}$ & Nov.18 & Dec.9 & 21 & Feb.15 & 68 & March,28 & 41 \\
$\mathrm{I}_{4}$ & Nov.18 & Dec.9 & 21 & Feb.21 & 74 & - & - \\
\hline
\end{tabular}


Irrigation water requirements (IWR, m3fed-1)

The amount of water requirements for wheat is summation of water applied and the effective rainfall which it equals the incident rainfall $\times 0.7$ (Novica, 1979).

The values of seasonal applied water were affected by irrigation scheduling for different allowable soil moisture depletion by using pan evaporation method $\left(\mathrm{I}_{1}, \mathrm{I}_{2}, \mathrm{I}_{3}\right.$ and $\left.\mathrm{I}_{4}\right)$ in the two growing seasons, (Figure 1).

The highest value of seasonal applied water was recorded with pan evaporation method at $60 \%$ allowable soil moisture depletion and the values are $2006.76 \mathrm{~m}^{3} \mathrm{fed}^{-1}$. and $2011.8 \mathrm{~m}^{3} \mathrm{fed}^{-1}$. in the first and second seasons, respectively. Meanwhile, the lowest values $1693.44 \mathrm{~m}^{3} \mathrm{fed}^{-1}$. and 1716.12 $\mathrm{m}^{3} \mathrm{fed}^{-1}$. were recorded with irrigation treatment $\mathrm{I}_{4}$ in the first and second seasons, respectively. Generally, seasonal water applied values can be descended in the following order; $\mathrm{I}_{3}>\mathrm{I}_{2}>\mathrm{I}_{1}>\mathrm{I}_{4}$ in the two seasons. Increasing values of seasonal applied water under irrigation treatment $\mathrm{I}_{3}$ could be attributed to long period of irrigation interval and hence, increasing the amount of water applied. These results are in a great harmony with those obtained by Beshara (2012) and Omar et al. (2014).

Actual water consumptive use(Eta, m3fed-1)

Actual water consumptive use was clearly affected by irrigation scheduling by pan evaporation method for different allowable soil moisture depletion in the two seasons, Fig. (2). In the two growing seasons, the maximum water consumptive use values $\left(1483.44 \mathrm{~m}^{3} \mathrm{fed}^{-1}\right.$. and $\left.1491 \mathrm{~m}^{3} \mathrm{fed}^{-1}\right)$ were recorded under irrigation treatment $1_{3}$ compared to the other irrigation treatments $\mathrm{I}_{1}, \mathrm{I}_{2}$ and $\mathrm{I}_{4}$. On the other hand, the lowest values were obtained under irrigation treatment $\mathrm{I}_{4}\left(1262.1 \mathrm{~m}^{3} \mathrm{fed}^{-1}\right.$ and $1285.2 \mathrm{~m}^{3} \mathrm{fed}^{-}$ ${ }^{1}$.), respectively. The values of water consumptive use can be arranged in the descending order as follows; $I_{3}>I_{2}>I_{1}>I_{4}$. Increasing the values of water consumptive use under irrigation treatment $\mathrm{I}_{3}$ could be attributed to increasing the amount of water applied and long period of irrigation interval. These results are in the same line with those obtained by Beshara (2012) and EL-Agrodi et al. (2016).

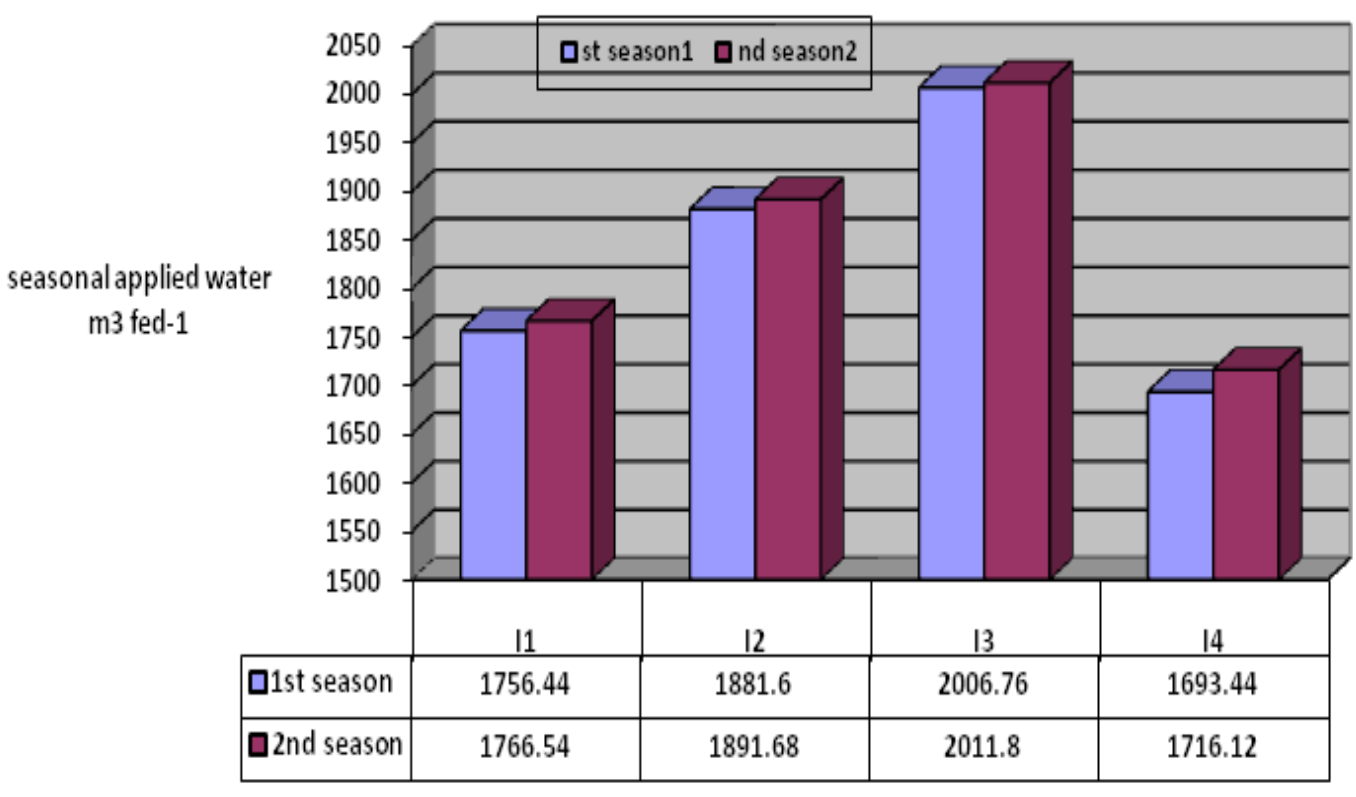

irrigation treaatments

Fig. 1. irrigation water requirements for different treatments in the two growing seasons 


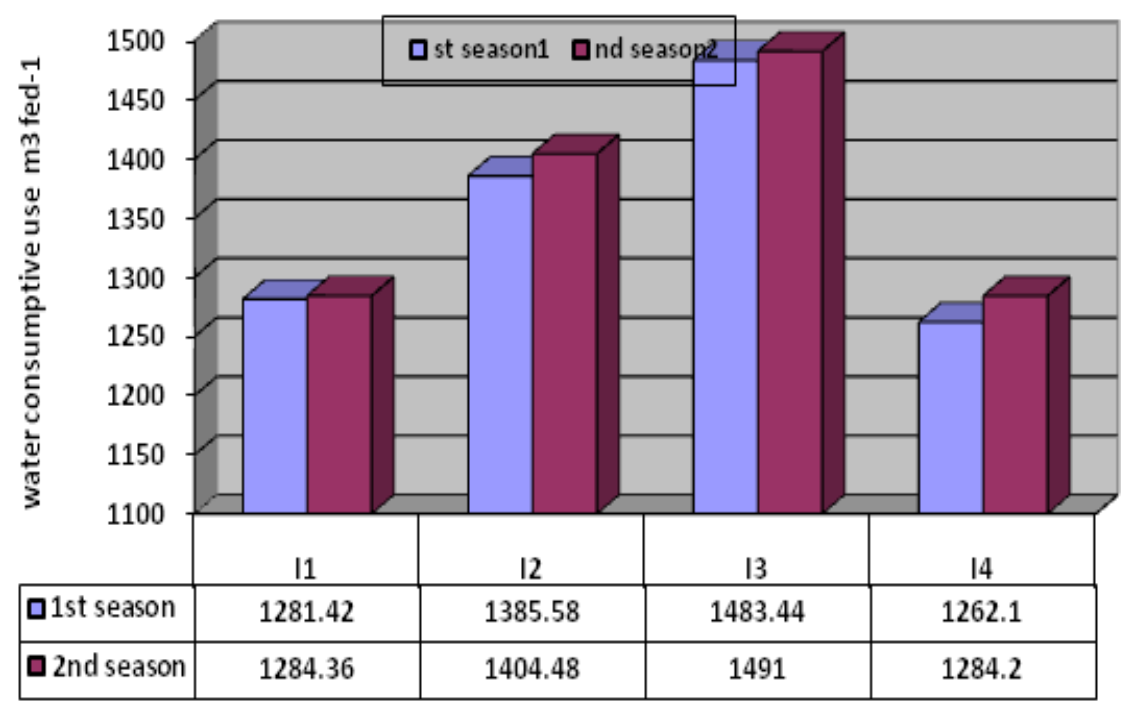

irrigation treaatments

Fig. 2. Effect of irrigation treatments on actual water consumptive use for wheat crop in the two growing seasons

Water storedand water application efficiency

Data in Table 6 showed that, values of water stored (Ws) and water application efficiency (Ea) were clearly influenced by irrigation treatments. The highest mean values of water stored were observed in $\mathrm{I}_{3}$ treatment, where the values are $1587.28 \mathrm{~m}^{3} \mathrm{fed}^{-1}$ and $1595.37 \mathrm{~m}^{3} \mathrm{fed}^{-1}$. in the first and second seasons, respectively. The lowest values were obtained with $\mathrm{I}_{4}$ treatment, where the values are $1350.45 \mathrm{~m}^{3} \mathrm{fed}^{-1}$ and $1364.27 \mathrm{~m}^{3} \mathrm{fed}^{-1}$. in the first and second seasons respectively. Generally, values of water stored can be descended in order; $\mathrm{I}_{3}>\mathrm{I}_{2}>\mathrm{I}_{1}>\mathrm{I}_{4}$ in the first and second seasons, respectively. These results are in agreement with those obtained by Beshara (2012).

Regarding the effect of irrigation treatments on water application efficiency, the values were clearly affected by irrigation treatments where the maximum values (79.75 and $79.5 \%$ ) were observed in $\mathrm{I}_{4}$ treatment which exposed to strict water stress and received three irrigations during the growth stages in the first and second seasons, respectively. The minimum values (78.06 and $77.56 \%$ ) were observed in $\mathrm{I}_{1}$ treatment. Generally, the values of water application efficiency can be descended in order; $\mathrm{I}_{4}>\mathrm{I}_{3}>\mathrm{I}_{2}>\mathrm{I}_{1}$ in the first season, while in the second season the order was as follows; $\mathrm{I}_{4}>\mathrm{I}_{2}>\mathrm{I}_{3}>\mathrm{I}_{1}$. These results were confirmed by Awan and Ali (1988).

Water productivity and productivity of irrigation water

The values of WP and PIW were greatly affected by irrigation scheduling at different allowable soil moisture depletion in both seasons. The highest values were obtained with I treatment where the WP values and PIW for wheat grain yield were found to be $\left(2.26\right.$ and $\left.1.65 \mathrm{kgm}^{-3}\right)$ in the first season, $\left(2.28\right.$ and $\left.1.66 \mathrm{kgm}^{-3}\right)$ in the second season, respectively. The values of WP and PIW for wheat straw yield were found to be (2.77 and $2.02 \mathrm{kgm}^{-3}$ ) in the first season, while in the second season were $\left(2.85\right.$ and $\left.2.07 \mathrm{kgm}^{-3}\right)$, respectively. Meanwhile, the lowest values of WP and PIW for wheat grain and straw yield were obtained with $\mathrm{I}_{3}$ treatment in the first and second seasons, respectively, Table 7 . The findings might be due to decreasing the amount of water consumptive use and water applied compared to other irrigation treatments. These results are in harmony with those obtained by EL-Agrodi et al. (2016) and EL-Mantawy and Khalifa (2018).

\section{Yield and some yield attributes \\ Plant height $(\mathrm{cm})$}

Data presented in Table 8 indicated that the plant height wasaffected significantlywith irrigation treatments in the first season, while in the second season there is no significant effect. It is clear that the tallest plants were produced under $I_{1}$ treatment where the values were $(95$ and $97 \mathrm{~cm})$ in the first and second seasons, respectively. The shortest plants were recorded with $\mathrm{I}_{4}$ treatment (89 and $91 \mathrm{~cm}$ ) in the two growing seasons. The decreased in plant height may be due to the reduction of cell expansion under water stress. Also, the increase in number of irrigations lead to increased nutrition availability and thus increase plant growth especially plant height, increasing the size and number of cells between the internodes which resulting in increasing the plant height. These results are in harmony with those found by Sharshar (2010), Omar et al., (2014) and Belal Hossain et al, (2015). 
TABLE 6. Effect of irrigation treatments on water stored $\left(\mathrm{m}^{3} \mathrm{fed}^{-1}\right)$ and water application efficiency (\%)

\begin{tabular}{|c|c|c|c|c|c|c|}
\hline \multirow[b]{2}{*}{$\begin{array}{l}\text { Irrigation } \\
\text { treatments }\end{array}$} & \multicolumn{3}{|c|}{$1^{\text {st }}$ season } & \multicolumn{3}{|c|}{$2^{\text {nd }}$ season } \\
\hline & $\begin{array}{l}\text { Water stored } \\
\qquad\left(\mathrm{m}^{3} \text { fed }^{-1}\right)\end{array}$ & $\begin{array}{l}\text { Water applied } \\
\qquad\left(\mathrm{m}^{3} \mathrm{fed}^{-1}\right)\end{array}$ & $\begin{array}{c}\text { Water } \\
\text { application } \\
\text { efficiency } \\
(\%)\end{array}$ & $\begin{array}{c}\text { Water } \\
\text { stored } \\
\left(\mathbf{m}^{3} \text { fed }^{-1}\right)\end{array}$ & $\begin{array}{l}\text { Water applied } \\
\qquad\left(\mathrm{m}^{3} \text { fed }^{-1}\right)\end{array}$ & $\begin{array}{c}\text { Water } \\
\text { application } \\
\text { efficiency } \\
(\%)\end{array}$ \\
\hline $\mathrm{I}_{1}$ & 1371.12 & 1756.44 & 78.06 & 1370.16 & 1766.54 & 77.56 \\
\hline $\mathrm{I}_{2}$ & 1482.57 & 1881.6 & 78.79 & 1502.79 & 1891.68 & 79.44 \\
\hline $\mathrm{I}_{3}$ & 1587.28 & 2006.76 & 79.1 & 1595.37 & 2011.8 & 79.3 \\
\hline $\mathrm{I}_{4}$ & 1350.45 & 1693.44 & 79.75 & 1364.27 & 1716.12 & 79.5 \\
\hline
\end{tabular}

TABLE 7. Effect of irrigation treatments on water productivity (WP, $\mathrm{kg} \mathrm{m}^{-3}$ ) and productivity of irrigation water (PIW, $\mathrm{kg} \mathrm{m}^{-3}$ ) for grain and straw yield in the two growing seasons

\begin{tabular}{ccccccccc}
\hline & \multicolumn{3}{c}{ For Wheat grain yield } & \multicolumn{3}{c}{ For Wheat straw yield } \\
\cline { 2 - 8 } $\begin{array}{c}\text { Irrigation } \\
\text { treatments }\end{array}$ & \multicolumn{2}{c}{$\mathbf{1}^{\text {st }}$ season } & \multicolumn{2}{c}{$\mathbf{2}^{\text {nd }}$ season } & \multicolumn{2}{c}{$\mathbf{1}^{\text {st }}$ season } & $2^{\text {nd }}$ season \\
& WP & PIW & WP & PIW & WP & PIW & WP & PIW \\
\hline$I_{1}$ & 2.26 & 1.65 & 2.28 & 1.66 & 2.77 & 2.02 & 2.85 & 2.07 \\
$I_{2}$ & 1.99 & 1.47 & 2.06 & 1.53 & 2.46 & 1.81 & 2.47 & 1.83 \\
$I_{3}$ & 1.76 & 1.3 & 1.82 & 1.35 & 2.17 & 1.6 & 2.19 & 1.63 \\
$I_{4}$ & 1.99 & 1.48 & 2.04 & 1.53 & 2.35 & 1.75 & 2.37 & 1.78 \\
\hline
\end{tabular}

TABLE 8. Effect of irrigation treatments on plant height $(\mathrm{cm})$, spike length $(\mathrm{cm})$ and kernel weight $(\mathrm{g})$ for wheat crop in the two growing seasons

\begin{tabular}{|c|c|c|c|c|c|c|}
\hline \multirow{2}{*}{ Irrigation treatments } & \multicolumn{2}{|c|}{ Plant height (cm) } & \multicolumn{2}{|c|}{ Spike length (cm) } & \multicolumn{2}{|c|}{1000 grain weight (g) } \\
\hline & $1^{\text {st }}$ season & $2^{\text {nd }}$ season & $1^{\text {st }}$ season & $2^{\text {nd }}$ season & $1^{\text {st }}$ season & $2^{\text {nd }}$ season \\
\hline $\mathrm{I}_{1}$ & 95 & 97 & 10.1 & 10.2 & 49.9 & 50.1 \\
\hline $\mathrm{I}_{2}$ & 93 & 95 & 9.8 & 9.9 & 47.8 & 48.2 \\
\hline $\mathrm{I}_{3}$ & 91 & 92 & 9.4 & 9.6 & 46.1 & 46.9 \\
\hline $\mathrm{I}_{4}$ & 89 & 91 & 9.1 & 9.3 & 45.2 & 45.7 \\
\hline F test & $*$ & NS & $* *$ & $* *$ & $* *$ & $* *$ \\
\hline L.S.D 0.05 & 3.996 & - & 0.3996 & 0.3996 & 0.4613 & 0.3996 \\
\hline L.S.D0.01 & - & - & 0.6054 & 0.6054 & 0.6988 & 0.6054 \\
\hline
\end{tabular}

*,** and NS indicate $\mathrm{p}<0.05,<0.01$ and not significant, respectively.

J. Sus. Agric. Sci. 45, No. 1 (2019) 
Spike length (cm)

Spike length exhibited highly significant effect due to irrigation treatments. The maximum spike length was produced under $\mathrm{I}_{1}$ treatment, while the minimum spike length was recorded under $\mathrm{I}_{4}$ treatment in the two growing seasons, (Table 8).

\section{0 grain weight $(g)$}

Irrigation treatments showed a highly significant effect on 1000 grain weight in the two growing seasons. It is clear from data that the highest value of 1000 grain weight was observed with $I_{1}$ treatment and the lowest value of grain weight was obtained with $\mathrm{I}_{4}$ treatment, Table, 10. The increase of 1000 grain weight is due to increase the available water and nutrients from the soil to plant lead to increase vegetative growth and thereby increase the metabolic rate and thus storage in grain, hence resulted in increasing grain weight. It is agreement with those reported by Sharshar(2010), AL-Tahar et al., (2011) and Omar et al., (2014).

\section{Biological yield}

The different irrigation treatments had highly significant effect on biological yield in the two growing seasons. It is clear that the maximum biological yield values were produced under irrigation scheduling treatment at $40 \%$ allowable soil moisture depletion, while the minimum values were obtained under irrigation scheduling at $70 \%$ allowable soil moisture depletion, Table 9.

\section{Grain yield}

Data in Table 9 indicates that there is not significant effect on grain yield due to irrigation treatments in both seasons. The highest wheat grain yield values were achieved with $\mathrm{I}_{1}$ - treatment followed by $\mathrm{I}_{2}$-treatment in the two growing season, respectively, while the minimal values of grain yield recorded with $\mathrm{I}_{4}$ treatment. Several investigators reported that inadequate irrigation water or drought stress reduced photosynthesis and translocation rates and increased respiration which reduced available assimilation for grain and finally decreased grain yield. These results agreed with those obtained by Sharshar (2010); Omar et al., (2014); EL-Agrodi et al, (2016); ELMantawy and Khalifa (2018).

\section{Straw yield}

Irrigation treatments had nosignificant effect on straw yield in the two growing seasons. The topmost yield was obtained with $\mathrm{I}_{1}$ treatment, while the lowest values of straw yield were recorded with $\mathrm{I}_{4}$ treatment in both seasons, Table 9. The increase in straw yield could be due to augment the amounts of irrigation water and hence increases yield components such as number of productive tillers and growth attributes. These are in agreement with discussion obtained by EL-Hag (2011) and Farhat (2015).

\section{Harvest index}

Data in Table 9 revealed that the irrigation treatments had high significant effect on harvest index in the first season, while irrigation treatments had insignificant effect in the second season. The maximum harvest index value was obtained through $\mathrm{I}_{1}$ treatment, while lowest value was obtained with $\mathrm{I}_{4}$ treatment in both seasons.

\section{Economic evaluation}

Total seasonal returns

The mean total seasonal return values for different irrigation scheduling were 12353.4, 11832.6, 11159.4 and 10590.6 LEfed $^{-1}$ for $\mathrm{I}_{1}$, $\mathrm{I}_{2}, \mathrm{I}_{3}$ and $\mathrm{I}_{4}$ treatments respectively in the first season, while the corresponding values in the second season were 12594.6, 12257.4, 11538.6 and 10997.4 LEfed ${ }^{-1}$ for the stated treatments. The highest values in both seasonswere obtained with $I_{1}$ treatment and the lowly values was recorded with $\mathrm{I}_{4}$ treatment, Table (10). It is worth to noting that the differences in the seasonal values of total return between and within treatments in the first season were less than those of the same treatments in the second season. These results may be due to variation in environmental or climatic factors during the two growing seasons.

\section{Net seasonal return}

Data in Table 10 revealed that the net seasonal revenue showed the same trend as in the abovementioned indicator (i. e. the seasonal total return). This trend may be due to that the production cost for each treatment separately seemed to be semifixed, or that the differences between them are relatively very small.The highest values of net return were achieved with $\mathrm{I}_{1}$ treatment, while the lowest values were recorded with $\mathrm{I}_{4}$ treatment in both seasons.

\section{Benefitcost ratio (BCR)}

From the presented data in Table 10, the same trend of the abovementioned economic indicators appears obviously, that it prevalent with this indicator in both growing seasons. The irrigation scheduling at $40 \%$ allowable soil moisture depletion by using pan evaporation increased the values of BCR compared to other irrigation treatments in both seasons. This finding may attributed to the relatively fixed cost between treatments on one hand, compared to considered differences in return between those treatments. The values of benefit cost ratio can be descended in the following order; $\mathrm{I}_{1}>\mathrm{I}_{2}>\mathrm{I}_{3}>$ $\mathrm{I}_{4}$ for both seasons. 
TABLE 9. Effect of irrigation treatment on biological yield, grain yield, straw yield and harvest index in the two growing seasons

\begin{tabular}{|c|c|c|c|c|c|c|c|c|}
\hline \multirow{2}{*}{$\begin{array}{l}\text { Irrigation } \\
\text { treatments }\end{array}$} & \multicolumn{2}{|c|}{$\begin{array}{l}\text { Biological yield } \\
\quad\left(\text { ton } \text { fed }^{-1}\right)\end{array}$} & \multicolumn{2}{|c|}{$\begin{array}{l}\text { Grain yield } \\
\left.\text { (ton fed }^{-1}\right)\end{array}$} & \multicolumn{2}{|c|}{$\begin{array}{l}\text { Straw yield } \\
\left.\text { (ton fed }^{-1}\right)\end{array}$} & \multicolumn{2}{|c|}{$\begin{array}{c}\text { Harvest index } \\
\% \%\end{array}$} \\
\hline & $1^{\text {st }}$ season & $2^{\text {nd }}$ season & $1^{\text {st }}$ season & $2^{\text {nd }}$ season & $1^{\text {st }}$ season & $2^{\text {nd }}$ season & $1^{\text {st }}$ season & $2^{\text {nd }}$ season \\
\hline $\mathrm{I}_{1}$ & 6.44 & 6.59 & 2.89 & 2.93 & 3.55 & 3.66 & 44.88 & 44.46 \\
\hline $\mathrm{I}_{2}$ & 6.18 & 6.36 & 2.76 & 2.89 & 3.41 & 3.47 & 44.78 & 44.44 \\
\hline $\mathrm{I}_{3}$ & 5.83 & 5.99 & 2.61 & 2.72 & 3.22 & 3.27 & 44.72 & 44.41 \\
\hline $\mathrm{I}_{4}$ & 5.48 & 5.67 & 2.51 & 2.62 & 2.97 & 3.05 & 44.7 & 44.21 \\
\hline F test & $* *$ & $* *$ & Ns & Ns & Ns & Ns & $* *$ & Ns \\
\hline L.S.D 0.05 & 0.057 & 0.045 & - & - & - & - & 0.098 & - \\
\hline L.S.D0.01 & 0.0856 & 0.068 & - & - & - & - & 0.148 & - \\
\hline
\end{tabular}

*,** and NS indicate $\mathrm{p}<0.05,<0.01$ and not significant, respectively.

TABLE 10. Values of total return, cost, net return and some economic criteria for wheat production in the two growing season

\begin{tabular}{|c|c|c|c|c|c|c|c|c|}
\hline \multirow{2}{*}{ Treatments } & \multicolumn{2}{|c|}{$\begin{array}{l}\text { Productivity } \\
\left.\text { (kg fed }^{-1}\right)\end{array}$} & \multirow{2}{*}{$\begin{array}{c}\text { Total } \\
\text { seasonal } \\
\text { return } \\
\text { (LE Fed }{ }^{-1)}\end{array}$} & \multirow{2}{*}{$\begin{array}{c}\text { Total } \\
\text { seasonal } \\
\text { costs } \\
\left(\text { LE Fed }^{-1}\right)\end{array}$} & \multirow{2}{*}{$\begin{array}{c}\text { Net seasonal } \\
\text { return } \\
\left(\text { LE Fed }^{-1)}\right.\end{array}$} & \multirow{2}{*}{$\begin{array}{c}\text { IWR } \\
\left(\mathrm{m}^{3} \mathrm{Fed}^{-1}\right)\end{array}$} & \multirow{2}{*}{ 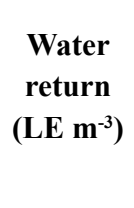 } & \multirow{2}{*}{ BC R } \\
\hline & grain & straw & & & & & & \\
\hline \multicolumn{9}{|c|}{$1^{\text {st }}$ season } \\
\hline $\mathrm{I}_{1}$ & 2890.5 & 3550 & 12353.40 & 6224 & 6129.40 & 1756.44 & 3.49 & 1.98 \\
\hline $\mathrm{I}_{2}$ & 2764.5 & 3410 & 11832.60 & 6224 & 5608.60 & 1881.6 & 2.98 & 1.90 \\
\hline $\mathrm{I}_{3}$ & 2605.5 & 3220 & 11159.40 & 6244 & 4915.40 & 2006.76 & 2.45 & 1.79 \\
\hline $\mathrm{I}_{4}$ & 2509.5 & 2970 & 10590.60 & 6154 & 4436.60 & 1693.44 & 2.62 & 1.72 \\
\hline \multicolumn{9}{|c|}{$2^{\text {nd }}$ season } \\
\hline $\mathrm{I}_{1}$ & 2929.5 & 3660 & 12594.60 & 6224 & 6370.6 & 1766.54 & 3.61 & 2.02 \\
\hline $\mathrm{I}_{2}$ & 2890.5 & 3470 & 12257.40 & 6224 & 6033.4 & 1891.68 & 3.19 & 1.97 \\
\hline $\mathrm{I}_{3}$ & 2719.5 & 3270 & 11538.60 & 6244 & 5294.6 & 2011.8 & 2.63 & 1.85 \\
\hline $\mathrm{I}_{4}$ & 2620.5 & 3050 & 10997.40 & 6154 & 4843.4 & 1716.12 & 2.82 & 1.79 \\
\hline
\end{tabular}


TABLE 11. Experimental return / costs by treatments during the two growing seasons

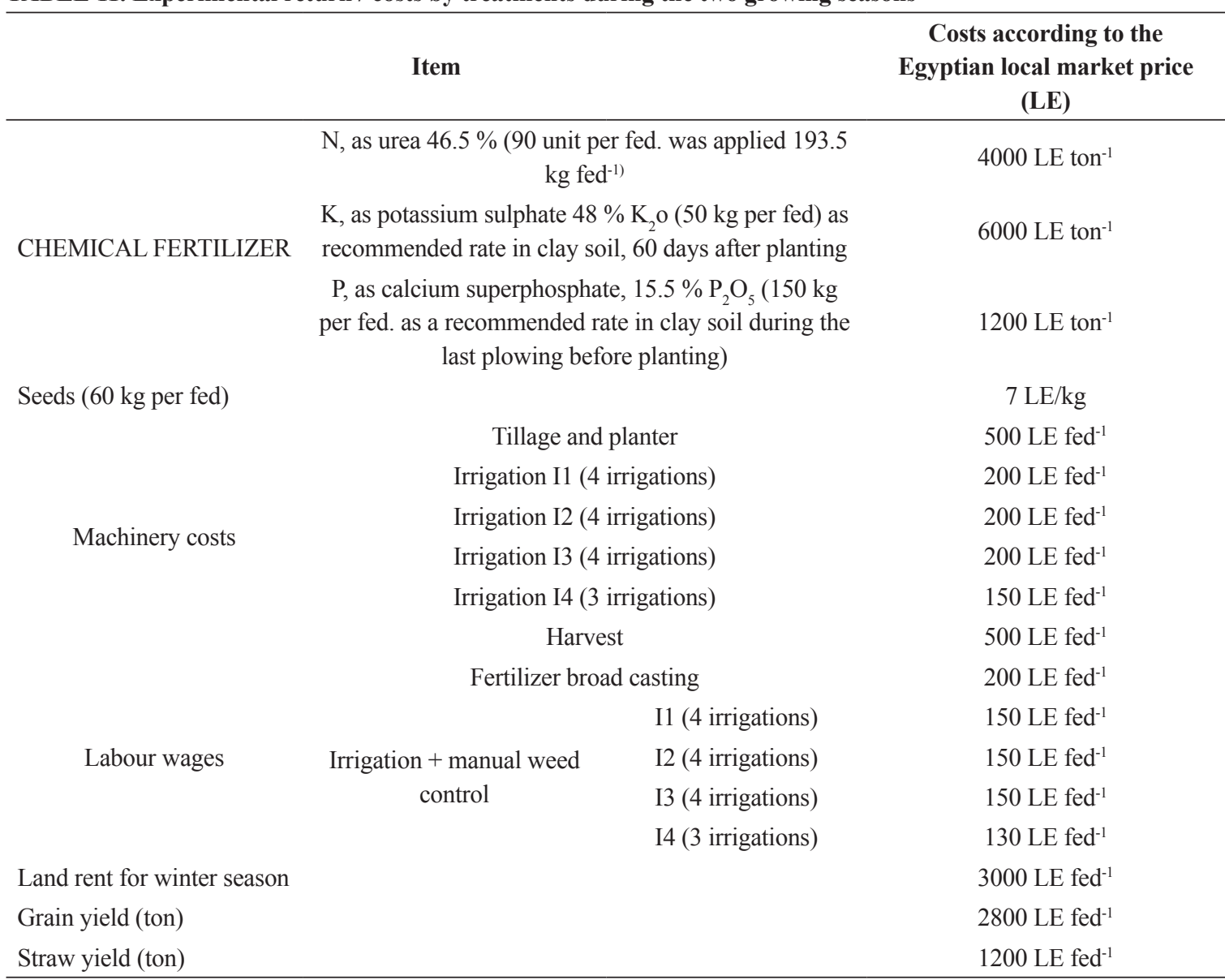

\section{Water returns}

It is clear from the data exhibited in Table (10) that the water return for different treatments showed the same tendency to those of previous indicators, in which the water return increased with increasing allowable soil moisture depletion. The highest values were obtained with $\mathrm{I}_{1}$ treatment, while the lowest values were recorded with $\mathrm{I}_{3}$ treatment in both seasons, this may be due to increasing the amounts of water applied between the treatments.

Selecting the most profitable treatment for wheat crop production

Sixparameters were taken into account to select the profitable treatment for wheat crop production under Egyptian conditions. These parameters related to; grain yield, straw yield, weight of 1000 grain, water productivity, productivity of irrigation water and benefit cost ration as shown in Table (12).It is suggested to use a factor called overall relative factor of evaluation, Kt. This factor is expressed as follows:
$\mathrm{K}=\mathrm{R}_{1} \mathrm{~K}_{1} \times \mathrm{R}_{2} \mathrm{~K}_{2} \times \mathrm{R}_{3} \mathrm{~K}_{3} \times \mathrm{R}_{4} \mathrm{~K}_{4} \times \mathrm{R}_{5} \mathrm{~K}_{5} \times \mathrm{R}_{6} \mathrm{~K}_{6}$ (Beshara, 2012)

where

$\mathrm{K}_{1}=$ Grain yield for the tested treatment/the same criterion for $\mathrm{I}_{1}$

$\mathrm{K}_{2}=$ Straw yield for the tested treatment/the same criterion forI

$\mathrm{K}_{3}=$ Weight of 1000 grains for the tested treatment / the same criterion for $\mathrm{I}_{1}$

$\mathrm{K}_{4}=$ Water productivity for the tested treatment/ the same criterion for $I_{1}$

$\mathrm{K}_{5}=$ Productivity of irrigation water for the tested treatment/ the same criterion for $\mathrm{I}_{1}$

$\mathrm{K}_{6}=$ Benefit cost Ratio for the tested treatment / the same criterion for $I_{1}$

The combined of these parameters may help to set up an overall relative factor of evaluation for each treatment and selecting an optimum treatment that meet the best results of all or most 
evaluation features. The importance of each parameter differs according to marketing and environmental conditions. So, the values of Ri, I $=1-6$ were taken throughout this work to be equal the unity. This simplifies the abovementioned formula to be as follows:

$$
\mathrm{K}_{\mathrm{t}}=\mathrm{K}_{1} \times \mathrm{K}_{2} \times \mathrm{K}_{3} \times \mathrm{K}_{4} \times \mathrm{K}_{5} \times \mathrm{K}_{6}
$$

It should be noted that $I_{1}$ treatment values were used in this research as a basis to calculate the values of the overall relative factor of evaluation $\left(\mathrm{K}_{\mathrm{t}}\right)$ for all other treatments. So, the values of $\mathrm{K}_{1}$ to $\mathrm{K}_{6}$ for the treatment of $\mathrm{I}_{1}$ should be equal unity, and consequently, the value of $\mathrm{K}_{\mathrm{t}}$ for the base treatment $\left(\mathrm{I}_{1}\right)$ must also be equal to unity. Table (12) shows the values of $\mathrm{K}_{1}, \mathrm{~K}_{2}, \mathrm{~K}_{3}, \mathrm{~K}_{4}, \mathrm{~K}_{5}$ and $\mathrm{K}_{6}$ for the different investigated treatments and the corresponding values of overall factors of evaluation. From the data presented in Table (13), it is clear that the value of overall factor $\left(\mathrm{K}_{\mathrm{t}}\right)$ of evaluation differs according to the investigated treatment. So, the different tested treatments of wheat production can be arranged in the following descending order:

$I_{1}>I_{2}>I_{4}>I_{3}$ in the first and second seasons respectively.

TABLE 12. Values of some features used for selecting the profitable treatment for wheat in the two growing season

\begin{tabular}{ccccccc}
\hline Treatments & $\begin{array}{c}\text { Grain yield } \\
\left(\mathbf{k g ~ f e d ~}^{-1}\right)\end{array}$ & $\begin{array}{c}\text { Straw yield } \\
\left(\mathbf{k g ~ f e d}^{-1}\right)\end{array}$ & $\begin{array}{c}\text { Weight of } \\
\mathbf{1 0 0 0} \text { grain } \\
(\mathbf{g})\end{array}$ & $\begin{array}{c}\text { WP } \\
\left(\mathbf{k g ~ m}^{-3}\right)\end{array}$ & $\begin{array}{c}\text { PIW } \\
\left(\mathbf{k g ~ m}^{-3}\right)\end{array}$ & BC R \\
\hline $\mathrm{I}_{1}$ & 2890.5 & 3550 & 49.9 & 2.26 & 1.65 & 1.98 \\
$\mathrm{I}_{2}$ & 2764.5 & 3410 & 47.8 & 1.99 & 1.47 & 1.90 \\
$\mathrm{I}_{3}$ & 2605.5 & 3220 & 46.1 & 1.76 & 1.3 & 1.79 \\
$\mathrm{I}_{4}$ & 2509.5 & 2970 & 45.2 & 1.99 & 1.48 & 1.72 \\
$\mathrm{I}_{1}$ & & & & & & \\
$\mathrm{I}_{2}$ & 2929.5 & 3660 & 50.1 & 2.28 & 1.66 & 2.02 \\
$\mathrm{I}_{3}$ & 2890.5 & 3470 & 48.2 & 2.06 & 1.53 & 1.97 \\
$\mathrm{I}_{4}$ & 2719.5 & 3270 & 46.9 & 1.82 & 1.35 & 1.85 \\
\hline
\end{tabular}

TABLE 13. Relative coefficient and overall relative coefficient of different irrigation treatments in the two growing season.

\begin{tabular}{|c|c|c|c|c|c|c|c|c|}
\hline Treatments & K1 & K2 & K3 & K4 & K5 & K6 & $\mathbf{K t}$ & order \\
\hline \multicolumn{9}{|c|}{$1^{\text {st }}$ season } \\
\hline $\mathrm{I}_{1}$ & 1.0 & 1.0 & 1.0 & 1.0 & 1.0 & 1.0 & 1.0 & 1 \\
\hline $\mathrm{I}_{2}$ & 0.956 & 0.961 & 0.958 & 0.881 & 0.891 & 0.960 & 0.662 & 2 \\
\hline $\mathrm{I}_{3}$ & 0.901 & 0.907 & 0.924 & 0.779 & 0.788 & 0.904 & 0.419 & 4 \\
\hline $\mathrm{I}_{4}$ & 0.868 & 0.837 & 0.906 & 0.881 & 0.897 & 0.869 & 0.451 & 3 \\
\hline \multicolumn{9}{|c|}{$2^{\text {nd }}$ season } \\
\hline $\mathrm{I}_{1}$ & 1.0 & 1.0 & 1.0 & 1.0 & 1.0 & 1.0 & 1.0 & 1 \\
\hline $\mathrm{I}_{2}$ & 0.987 & 0.948 & 0.962 & 0.904 & 0.922 & 0.975 & 0.731 & 2 \\
\hline $\mathrm{I}_{3}$ & 0.928 & 0.893 & 0.936 & 0.798 & 0.813 & 0.916 & 0.462 & 4 \\
\hline $\mathrm{I}_{4}$ & 0.895 & 0.833 & 0.912 & 0.895 & 0.922 & 0.886 & 0.497 & 3 \\
\hline
\end{tabular}

J. Sus. Agric. Sci. 45, No. 1 (2019) 


\section{Conclusion}

Although $I_{1}$ irrigation treatment received fewer amounts of irrigation water among other treatments, it suppressed all values of studied parameters. Also, irrigation treatments have no significant differences in wheat yield and $\mathrm{I}_{1}$ irrigation treatment also gave best values of yield and yield components. So, it can be concluded that the treatment $I_{1}$ is the best treatment (irrigation scheduling at allowable $40 \%$ depletion of available soil moisture) followed by $\mathrm{I}_{2}$ treatment which meet the best desired results such as the highest grain and straw yields and the highest water functions.

\section{References}

Ali, M. H., M. K. Hogue, A.A Hassan and A. Khair (2007) Effect of deficit irrigation on yield water productivity and economic returns of wheat. Agricultural water management, 92 (3), 151-161.

AL-Tahar, B., A. EL Hwary and S. O. Yagoub (2011) Effect of skipping irrigation on growth, yield, yield components and water use efficiency of wheat (Triticumaestivum L) in semi-arid region of Sudan. Agric. Bio. J. n. 2 (6), 1003-1009.

Ashraf, M., M. M. Saeed and M. N. Asghar (2001) Evaluation of resources conservation Technologies under skimmed groundwater applications. Journal of drainage and water management. 5 (2),1-10.

Ashraf, M., M. M. Saeed and M. N. Asghar (2002) Evaporation pan; A tool for irrigation scheduling. Journal of Drainage and water management, 6(1), 45-51.

Atiea, A. M. (1986) Economics of farm mechanization the Egyptian Public Authority for book 1986.

Awan. Q. A. and A. Ali (1988) Irrigation efficiencies in the farm irrigation system. Water as a constraint. Univ. of Agric. Faisalabad.

Belal Hossain Md.; Khandakar Faisal IbnMurad; Sariful Bin Ekram; Niaz Md. Farhat Rahman;Mahbubur Rashid Talukder and Mesbauddin Ahmed (2015) Scheduling of Wheat using Pan Evaporation Method. International Journal of Innovative Research in Advanced Engineering, Issue 10, Volume 2, 99-105

Beshara, A. T. (2012) Effect of soil moisture depletion and nitrogen fertilizer application date on wheat yields, water and fertilizer use efficiencies in North Africa. $P h D$ Thesis. Fac. Of Agric. Cairo Univ., Egypt.
Dewis, J. and Fartias (1970) Physical and chemical methods of soil and water analysis. Soil Bulletin No. 10, FAO, Rome.

Downy, L. A. (1970) Water use by maize at three plant density. Paper, 33 FAO, Rome.

EL-Agrodi, M. W. A.; M. M. Saeid; G. L. Ahmed and T. S. H.Khalifa (2016) Effect of soil moisture depletion and nitrogen levels on wheat (Triticumaestivum L.) J. Soil Sci. and Agric. Eng., Mansoura Univ., 7(2),169-178.

EL-Beltagy, A. T. and A. F. Abo-Hadeed (2008) The main pillars of the national program for maximizing the water use efficiency in the old land, The research and development council. MDALR (IN ARABIC) p.30.

EL-Hag, Dalia A.A. (2012) Effect of planting date and nitrogen level on yield and quality of bread and durum wheat. Ph.D. Thesis, Kafr El-Sheikh Univ., Egypt.

EL-Hag, Walaa,A. (2011) Evaluation of some cultivars and lines of bread wheat under low input. M.SC. Thesis, Kafr El-Sheikh Univ., Egypt.

Farhat, W. Z. E. (2015) Response of 21 spring bread wheat genotypes to normal and reduced irrigation in delta. Plant production Mansoura Univ., Vol. 6 (6), 943-963.

Gomez, K. A. and A. Gomez (1984) Statistical procedures for agricultural research. $1^{\text {sted. }}$ Johnwilley \& sons. New York.

Hansen, V. W., O. W, Israelson and Q. E. Stringarm (1979) Irrigation Principles and practices, $4^{\text {th }}$ ed. John Willey and sons, New Yourk.

Jackson, M. L. (1973)Soil chemical analysis prentice Hall India, Private Ltd. New Delhi

Karrou, M., T. Dweis; R. Abou El-Enein and M. sheri (2012) yield and water productivity of maize and wheat under deficit and raised bed irrigation practices in Egypt. African Journal of Agricultural of Research. 7, 1755-1760.

Khalil, F. A. (1996) Scheduling irrigation for Faba bean using evaporation pan method. M. Sc. College of agriculture. Zagazig University, Moshtohor city, Egypt.

Khalil, F. A. F., A. M. Tammam; I. A. Amin; and K. A. Mohamed (2006) Scheduling irrigation for some wheat cultivars under Upper Egypt conditions. Mansoura University. $J$ sciences. 31, 561-572. 
Klute, A. (1986) Water retention: Laboratory methods: In: A. Koute (ed). Methods of Soil Analysis, part 1, $2^{\text {nd }}$ ed. Agron. Monogr. 9, ASA, Madison, WIUSA, PP.635-660.

Masoud, F.I. (1969) Principles of Agricultural irrigation. Dar ELmatbouat Elgadidah, Alexandria (in Arabic).

Novica, V. (1979) Irrigation of agriculture crops. Fac. Agric. Press, Novi sad Yugoslavia.

Omar, A.M., A.A.E. Mohamed, M.S.A. Sharshar, Walaa. A.A. ELhag (2014) Performance of some bread wheat genotypes underwater regime and sowing methods. J. Agric. Res. Kafr El-Sheikh Univ. 40 (2), 327-341.

Rania F.EL-Mantawy and R. M. Khalifa (2018) Response of Barley plants to potassium spraying under water deficit conditions. J. Plant Production, Mansoura Univ., 9 (4), 359-367.

Sharshar, A. M. (2010) combining ability and heterosis for bread wheat under stress and normal irrigation numbers M.Sc. Thesis, Kafr El-Sheikh Univ.

Wei, Z. Dong, C. Zhang, S. Ali, X Chen, Q. Han, F. Zhang, Z. Jia, P. Zhang and X. Ren (2018) Effects of rainwater harvesting planting combined with deficiency irrigation on soil water use effeciency and winter wheat (Triticumae stivum L.) yield in a semiarid area. Field Crops Research, 218 (2018) 231-242.

Wen, S. Shang and J. Yang (2017) Optimization of irrigation scheduling for spring wheat with mulching and limited irrigation water in an arid climate. Agricultural Water Management, 192, 3344.

Zafarnaderi, N. S. A. and S. A. Mohammadi (2013) Relationship between grain yield and related agronomic traits in bread wheat recombinant inbred lines under water deficit condition. Annals of Biological Research 4 (4), 7-11.

Zhang, W. Qin, S. Chen, L. Shao, H. Sun (2017) Response of yield and WUE of winter wheat to water stress during the past three decades- A case study in the North China Plain. Agricultural Water Management, 179, 47-54. 


\section{تأثثر جدولة الري عند مستويات مختلفة من استتفاذ الرطوبة الأرضية الميسرة باستخدام

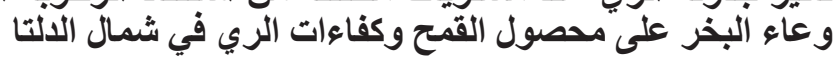

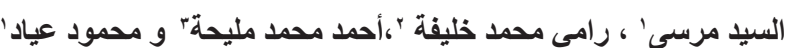

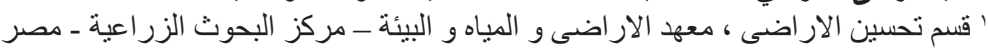

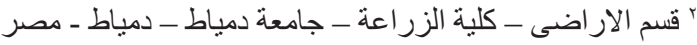

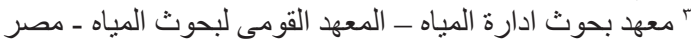

أجريت تجربة حقلية في محطة البحوث الزراعية بسخا - محافظة كفر الثيخ خلال موسمين زراعيين

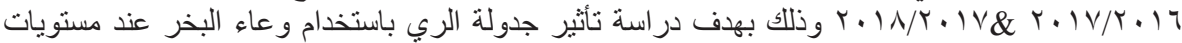

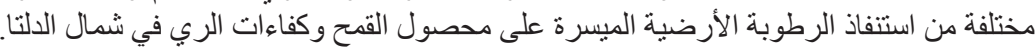

تم اختبار أربع معاملات للاري: وهي جدولة الري باستخدام و عاء البخر عند استنفاذ نسب مختلفة من

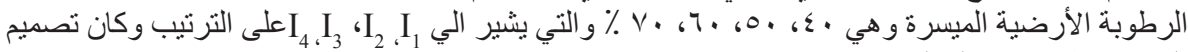
التجربة قطاعات كاملة العشو ائية.

ويمكن تلخيص النتائج المتحصل عليها: -

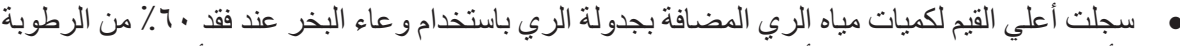

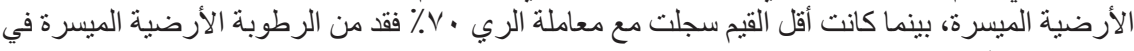
كلا موسمي الدراسة.

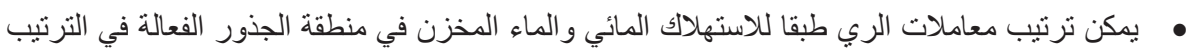

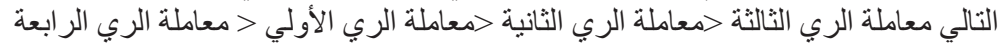

• اتضح من النتائج أن معاملة الري الأولي تفوقت على باقي المعاملات الأخرى في زيادة الإنتاجية المائية

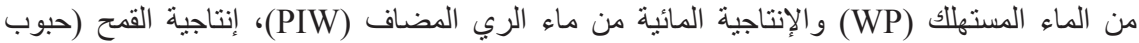
وقشومكوناته) بالإضافة الي محصول الحبوب، العائد الموسمي الكلي، صافي الزئي العائد ونسبة العائد الي التكلفة.

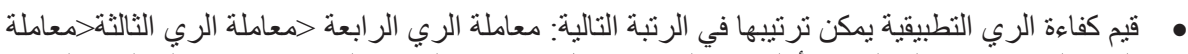

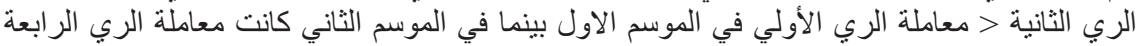

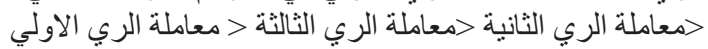

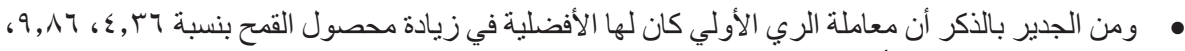

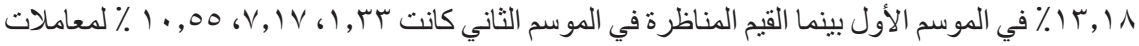

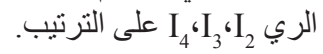

• تحت ظروف الدراسة الحالية يمكن التوصية بالري بالمعاملة الأولي (وهي جدولة الري باستخدام و عاء الراء

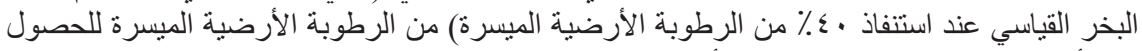

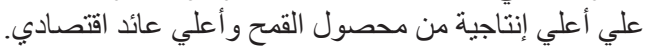

